\title{
STRUCTURAL PERFORMANCE ANALYSIS AND DESIGN OF ROOF MOUNTED SOLAR PANELS
}

\author{
Meghana A Patankar', Sripadraj K Kanchi ${ }^{2}$, Rajesha $R$ N $^{3}$, Prasanna Kumar ${ }^{4}$ \\ ${ }^{I}$ M.Tech Student, Civil EngineeringDepartment, Bangalore Institute of Technology, Bengaluru, Karnataka, India \\ ${ }^{2}$ M.Tech Student, Civil Engineering Department, Bangalore Institute of Technology, Bengaluru, Karnataka, India \\ ${ }^{3}$ M.E Student, Civil Engineering Department, University Visvesvaraya College of Engineering (BU), Bengaluru, \\ Karnataka, India \\ ${ }^{4}$ Managing Director, Smartminds Engineering PVT LTD, Bengaluru, Karnataka, India
}

\begin{abstract}
The use of non-renewable source of energy in generation of electricity has led to emission of pollutants which has caused global warming. The increase in pollution has created awareness in public to use renewable source of energy such as solar energy which can be harnessed without the release of harmful pollutants to the environment. In our study solar photovoltaic panels are fixed on roof of existing industrial building in Kolar district Karnataka. The main purpose of the analysis is to decide the structural sections and connections to support the solar panel which are mainly loaded by wind load. The analysis is done in accordance with IS-875(Part III) 1987and all the calculations are done manually as per codal provisions.
\end{abstract}

Keywords — Stability Analysis, Wind Parameters, Sectional Properties, Pitched Roof, Photovoltaic Panels.

\section{INTRODUCTION}

The use of non-renewable source of energy like coal, oil, gas in generation of electricity are getting scarce and has led to the emission of pollutants to atmosphere which has resulted in global warming. The results of a recent review of literature concluded that as greenhouse emitters begin to be held liable for resulting in climate change, a high value for liability mitigation would provide powerful incentives for development of renewable energy technologies like solar energy.

This project is about optimal structural design of solar panel supporting structure over a pitched roof of existing industrial building. In this study we are bringing forth the design challenges involved in finding optimized solutions to effectively resist the forces of wind and gravity on a solar panel structure. The existing factory building is located at Malur Kolar district about 80kms from Bengaluru. The solar PV panels are mounted on U-purlins which are in turn supported on existing building roof purlins. Roof top solar panel installation adds some dead load due to weight of panels and mounting systems. Once the size of the solar panel is fixed, the existing structure must be evaluated for added solar panel loads. The structural support systems for these building vary widely. Wood framed, wood truss, steel framed and pre engineering steel buildings are the most common type of supporting structures encountered. In this study, support section is given by Purlin and Channel section. When designing a new solar panel installation; wind, seismic and snow loads must be considered according to the region and efforts must be made to minimize their impact on existing structure. Roof top mounted solar panels are often located at the highest elevation of the structure and subjected to wind load. The solar panel mounting system's lateral load carrying capacity is often the limiting factor in the mounting system design and the wind forces are often responsible for generating the lateral loads in case of solar panel installation.

The diagrammatic representation of solar panel installation is as shown in Fig-1.

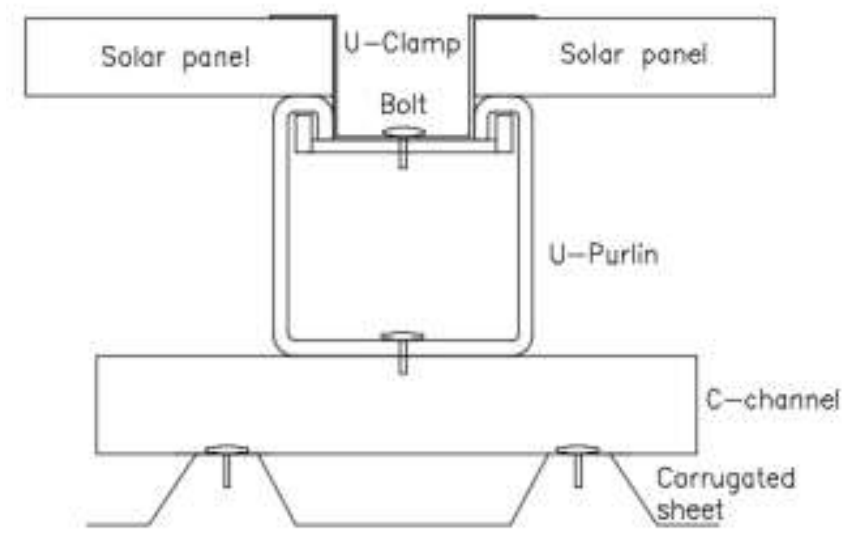

Existing sheet roof of the structure

Fig-1: Representation of solar panel installation

\section{OBJECTIVE}

During past few decades, the design of Roof Mounted Solar System received enough attention but Analysis and Design using Indian Standard Code have not been concentrated much. 
This paper concentrates on to check the performance of different type of purlins, so as to optimize the design of mounting system to resist all possible forces acting over it. For this two profiles of purlins are considered, the sections are as shown below in Fig-2 and Fig-3.

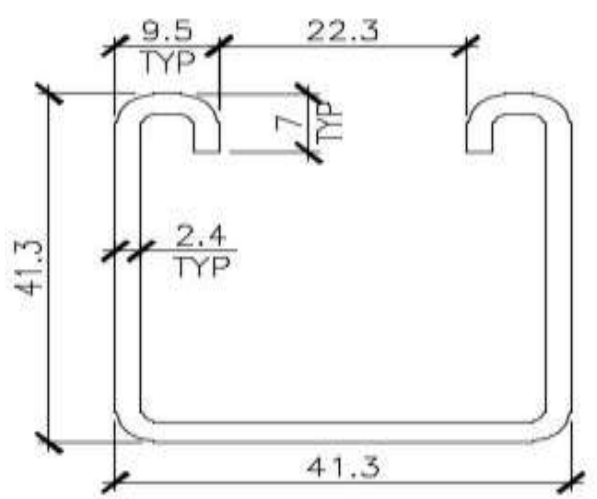

Fig-2: U-Purlin

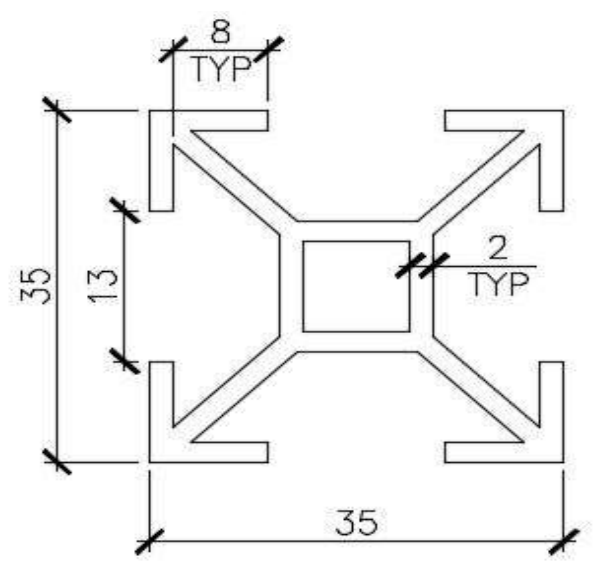

Fig-3: Star Section

\section{MASTER DATA}

Plan dimension of the $60.96 \mathrm{~m} \times 60.96 \mathrm{~m}$ structure

Height of the building $11.6 \mathrm{~m}$

Slope of the roof

Roof

6 Degree

Inaccessible, Corrugated sheet roofing

\section{DESIGN METHODOLOGY}

Self-weight of PV panel and number of panels per bay is calculated. Wind parameters like wind speed, wind pressure, pressure coefficient are determined according to IS 875 (part III) 1987. Further we proceed with calculation of moment capacity of purlin and capacity of bolt in accordance with IS 800: 2007. Finally pull-out strength of bolt is determined.

Self-weight of PV panel and number of PV panels per bay is given by;

$$
W_{1}=\frac{W_{g} * 9.81}{L * n} * N
$$

$$
\begin{array}{ll}
\boldsymbol{W}_{\boldsymbol{g}} & \text { Self-weight of solar panel } \\
\boldsymbol{N} & \text { Total number of PV panel per bay } \\
\boldsymbol{N} & \text { No of purlins } \\
\boldsymbol{L} & \text { Total span in longitudinal direction }
\end{array}
$$

Wind parameters like wind speed, wind pressure, external and internal pressure co-efficient are determined according to IS-875 (part III)-1987.

\section{Wind Parameters}

Design wind speed $\left(\mathbf{V}_{\mathbf{z}}\right)$ (Cl.5.3 IS 875 PART III)

$$
V_{z}=V_{b} * K_{1} * K_{2} * K_{3}
$$

$V_{b} \quad$ Basic wind speed

$\boldsymbol{K}_{\boldsymbol{I}} \quad$ Probability factor (risk coefficient) (CL.5.3.1)

$\boldsymbol{K}_{2} \quad$ Terrain, height and structure size factor (CL.5.3.2)

$K_{3} \quad$ Topography factor (CL.5.3.3)

Design wind pressure $\left(\mathrm{P}_{\mathrm{z}}\right)$ (Cl.5.4 IS 875 PART III)

$$
P_{z}=0.6 * V_{z}^{2}
$$

\section{Pressure Co-Efficient}

External pressure co-efficient $\left(\boldsymbol{C}_{\boldsymbol{p}}\right)$

External pressure co-efficient are taken from the Table 16 of IS: 875 (PART III) as factory building resembles.

Internal pressure co-efficient $\left(\boldsymbol{C}_{\boldsymbol{p} i}\right)$ IS: 875 (PART III) (Cl.6.2.3.2)

Medium opening i.e. 5 to $20 \%$ :- \pm 0.5

\section{Resultant Pressure}

$$
\boldsymbol{F}=\left(\boldsymbol{C}_{p e}-\boldsymbol{C}_{p i}\right) * \boldsymbol{A} * \boldsymbol{P}_{\boldsymbol{d}}
$$

$C_{p e} \quad$ External pressure coefficient

$C_{p i} \quad$ Internal pressure- coefficient

$\boldsymbol{A}$ Surface area of structural or cladding unit.

$\boldsymbol{P}_{\boldsymbol{d}} \quad$ Design wind pressure

Further we proceeded with calculation of moment carrying capacity of purlin and capacity of bolt in accordance with IS-800-2007. Finally pull-out strength of bolt is determined.

\section{Moment Capacity of Aluminium Purlin}

$$
Z=\frac{M}{f}
$$




$$
\begin{gathered}
M=f * Z \\
Z=\frac{I}{y}
\end{gathered}
$$

$\begin{array}{ll}\boldsymbol{F} & \text { Tensile strength of Aluminium purlin } \\ \boldsymbol{I} & \text { Moment of inertia of Aluminium purlin } \\ \boldsymbol{Y} & \text { Centroid of Aluminium purlin }\end{array}$

\section{Moment due to Load on Purlin}

$$
M=\frac{W L^{2}}{8}
$$

$$
\begin{array}{ll}
\boldsymbol{W} & \text { Wind load acting on purlin } \\
\boldsymbol{L} & \text { Centre to Centre distance between the } \\
& \text { purlin }
\end{array}
$$

NOTE: - For the structure to be safe the moment due to wind load on purlin should be less than the moment capacity of aluminium purlin.

\section{Calculation of bolt capacity}

\section{Shear capacity of the bolt, IS 800 (Cl.10.3.3)}

Design strength of the bolt is calculated as

$$
V_{d s b}=\frac{V_{n s b}}{r_{m b}}
$$

Where $\boldsymbol{V}_{\boldsymbol{n} \boldsymbol{b} \boldsymbol{b}}=$ Nominal shear capacity of a bolt, calculated as follows:

$$
V_{n s b}=\frac{f_{u}}{\sqrt{3}}\left(n_{n} A_{n b}+n_{s} A_{s b}\right)
$$

$f_{u} \quad$ Ultimate tensile strength of a bolt

$n_{n} \quad$ Number of shear planes with threads intercepting the shear plane

$\boldsymbol{n}_{\mathrm{s}} \quad$ Number of shear planes without threads $n_{s} \quad$ intercepting the shear plane

$\boldsymbol{A}_{s b} \quad$ Nominal plain shank area of the bolt

Net shear area of the bolt at threads, may be $\boldsymbol{A}_{\boldsymbol{n} \boldsymbol{b}} \quad$ taken as the area corresponding to root diameter at the thread.

\section{Bearing capacity of the Bolt, IS 800 (Cl.10.3.4)}

The design bearing strength of a bolt on any plate, $\mathrm{V}_{\mathrm{dpb}}$ as governed by bearing is given by

$$
V_{d p b}=\frac{V_{n p b}}{r_{m b}}
$$

$V_{n p b}=$ Nominal bearing strength of a bolt

$$
\boldsymbol{V}_{n p b}=2.5 * \boldsymbol{K}_{b} * \boldsymbol{d} * \boldsymbol{t} * \boldsymbol{f}_{\boldsymbol{u}}
$$

$\mathrm{K}_{\mathrm{b}}$ is smaller of $\frac{e}{3 * d_{o}}, \frac{P}{3 d_{0}}-0.25, \frac{f_{u b}}{f_{u}}, 1$
$e, p$
End and Pitch distances of the fastener along
bearing direction
$\boldsymbol{d}_{\boldsymbol{o}} \quad$ Diameter of the hole
$f_{u b}, f_{u} \quad$ Ultimate tensile stress of the bolt and the ultimate tensile stress of the plate
d Nominal diameter of the bolt
Summation of the thicknesses of the connected plates experiencing bearing stress in the same
$t \quad$ direction, or if the bolts are countersunk, the thickness of the plate minus one half of the depth of countersinking.

NOTE: - Design strength of the bolt is taken as minimum of strength obtained in shear and bearing.

\section{Tension capacity of the bolt, IS 800 (Cl.10.3.5)}

Design tension capacity of bolt is calculated as

$$
T_{d b}=\frac{T_{n d}}{r_{m b}}
$$

$\boldsymbol{T}_{\boldsymbol{n} \boldsymbol{d}}=$ Nominal tensile capacity of the bolt

$$
T_{n d}=0.9 * f_{u b} * A_{n}<f_{y b} * A_{s b} \frac{\Upsilon_{m b}}{\Upsilon_{m o}}
$$

$f_{u b} \quad$ Ultimate tensile stress of the bolt

$f_{y b} \quad$ Yield stress of the bolt

Net tensile stress area as specified in the appropriate Indian Standard (for bolts $\boldsymbol{A}_{\boldsymbol{n}} \quad$ where the tensile stress area is not defined, $A_{n}$ shall be taken as the area at the bottom of the threads)

$\boldsymbol{A}_{\mathrm{s} b} \quad$ Shank area of the bolt

\section{Pull-out force}

The pull-out strength is the force that would have to be applied to tear the screw out of its anchoring. It depends on the multiple factors like screw geometry, screwing in depth, materials used, thread length etc.

$$
\mathbf{F}=\mathbf{\tau} * \boldsymbol{\pi} * \mathbf{D}_{\mathbf{p}} * \mathbf{L} * \mathbf{S}
$$

$\begin{array}{ll}\mathbf{F} & \text { Pull-out force } \\ \mathbf{T} & \text { Shear stress }=\frac{\sigma_{t}}{\sqrt{3}} \\ \boldsymbol{\sigma}_{\mathbf{t}} & \text { Tensile yield stress or design stress } \\ \mathbf{D}_{\mathbf{p}} & \text { Pitch diameter } \\ \mathbf{L} & \text { Axial length of full thread engagement } \\ \mathbf{S} & \text { Safety factor }=\mathbf{1 . 2}_{\mathbf{1}} \mathbf{c}_{\mathbf{2}} \\ \mathbf{c}_{\mathbf{1}} & 1.0 \text { for special screws } \\ \mathbf{c}_{\mathbf{2}} & 1.5 \text { for ordinary screws } \\ \mathbf{c}_{\mathbf{2}} & 10 \varepsilon_{\mathrm{br}}(\geq 1.0) \\ \boldsymbol{\varepsilon}_{\mathrm{br}} & \text { Elongation at break }(\%)\end{array}$

NOTE: -Pull out force of bolt should always be greater than reaction at purlin where bolt connects. 


\section{DETAILED CALCULATION}

\subsection{Design Load Calculation for Multi-Span}

\section{Mounted Solar Power Project (C-Channel)}

Calculations are done in accordance with the formulae given in the design methodology.

Centre to Centre distance of Purlins $=1.5 \mathrm{~m}$

\section{Structural Parameters}

PV Panel dimensions

$\begin{array}{ll}\text { W } & 1.67 \mathrm{~m} \\ \mathrm{~B} & 0.91 \mathrm{~m} \\ \mathrm{~T} & 40 \mathrm{~m} \\ \text { Self-Weight of PV panel W } & 18 \mathrm{~kg} \\ \text { No. of Purlins per bay } & 11 \\ \text { Length in X direction 1 bayX } & 15.24 \\ \text { Length in Y direction 1 bayY } & 6.096 \\ \text { Total number of bays } & 10 \\ \text { Total number of PV panels Per } & 62 \\ \text { Bay } & \end{array}$

Self-Weight of PV panel on each purlin

$$
W_{1}=\frac{18 * 9.81}{6096 * 11} * 62
$$

$\boldsymbol{W}_{1}=0.17 \mathrm{~N} / \mathrm{mm}$

\section{Wind Parameters}

$\begin{array}{llll}\begin{array}{l}\text { Basic wind speed } \\ \text { (Kolar) }\end{array} & \boldsymbol{V}_{\boldsymbol{b}} & 33 \mathrm{~m} / \mathrm{s} \\ \begin{array}{l}\text { Probability factor } \\ \text { Terrain, height and }\end{array} & \boldsymbol{K}_{\boldsymbol{1}} & 1 \text { (CL.5.3.1) } \\ \text { structure size factor } & \boldsymbol{K}_{\boldsymbol{2}} & 0.99(\mathrm{CL} .5 .3 .2) \\ \text { Topography Factor } & \boldsymbol{K}_{3} & 1(\mathrm{CL} .5 .3 .3) \\ \begin{array}{l}\text { Design wind speed } \\ \text { Design wind pressure }\end{array} & \boldsymbol{V}_{\boldsymbol{z}} & 32.67 \mathrm{~m} / \mathrm{s} \\ \boldsymbol{P}_{z} & 640.4 \mathrm{~N} / \mathrm{m}^{2}\end{array}$

External pressure coefficient $\left(\boldsymbol{C}_{\boldsymbol{p} e}\right)$ for Pitched roof Multiplan building is given in Table 1.

Table 1: External pressure coefficient $\left(\boldsymbol{C}_{\boldsymbol{p} e}\right)$

Wind Force Calculations

$\begin{array}{lcll}\begin{array}{l}\text { Net-pressure } \\ \text { coefficient }\end{array} & \boldsymbol{C}_{\boldsymbol{p} \boldsymbol{e}} & \boldsymbol{C}_{\boldsymbol{p} i} & \\ \text { Roof A } & -2 & 0.5 & \text { Table 16,IS-875 } \\ \text { Roof B } & -1.5 & 0.5 & \text { PART III } \\ \text { Roof X } & -1.5 & 0.5 & \\ \text { Roof Z } & -2 & 0.5 & \end{array}$

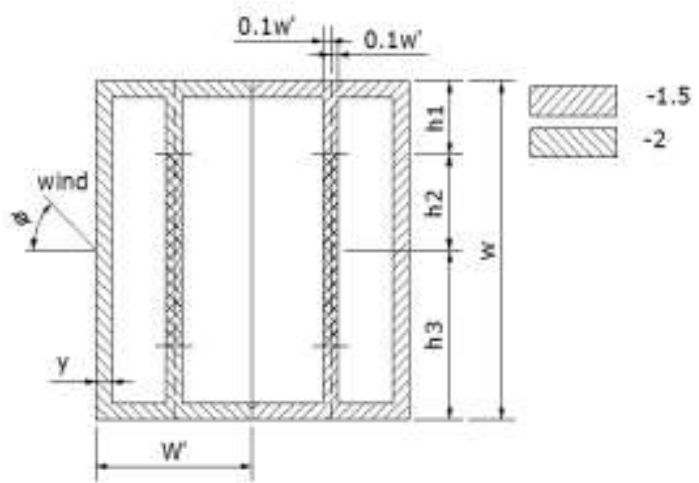

Fig 4. Representation of pressure coefficients

\section{Wind Blowing Perpendicular to the Ridge}

Windward $=$

$(-2-0.5) \times 1.5 \times 640.4 / 1000=-2.4 \mathrm{kN} / \mathrm{Mx}-1=2.4 \mathrm{KN} / \mathrm{M}$

Leeward $=$

$(-1.5-0.5) X 1.5 \times 640.4 / 1000=-1.92 \mathrm{KN} / \mathrm{Mx}-1=1.92 \mathrm{kN} / \mathrm{m}$

Tensile strength

195.00MPa

Width of purlin

$41.30 \mathrm{~mm}$

Height of purlin

$41.30 \mathrm{~mm}$

Thickness

$2.40 \mathrm{~mm}$

Neutral axis Depth

$20.65 \mathrm{~mm}(\mathrm{~d} / 2)$

(Assumed)

Aluminium purlin moment of $91230.40 \mathrm{~mm}^{4}$ inertia (From AutoCAD)

Maximum moment capacity of aluminium purlin

$$
\boldsymbol{M}=\frac{\boldsymbol{f}}{\boldsymbol{I}} * \boldsymbol{y}
$$

$\boldsymbol{f}=$ Tensile strength of Aluminium purlin

$\boldsymbol{I}=$ Moment of inertia of Aluminium purlin

$\boldsymbol{y}=$ Centroid of Aluminium purlin

$$
M=\frac{195}{20.65} * 91230.4
$$

$0.86 \mathrm{kN}-\mathrm{m}$

Moment due to Load on purlin

$0.68 \mathrm{kN}-\mathrm{m}$

$M=\frac{2.40 * 1.5^{2}}{8}=0.68 \mathrm{kN}-\mathrm{m}$

For the structure to be safe the moment due to wind load on purlin should be less than the moment capacity of aluminum purlin. 
5.2 Design Load Calculation for Multi-Span

Mounted Solar Power Project (Star Shaped Profile)

- for Extreme Values of External Pressure CoEfficient

Tensile strength

$195.00 \mathrm{MPa}$

Width of purlin

$35.00 \mathrm{~mm}$

Height of purlin

$35.00 \mathrm{~mm}$

Thickness

$2.40 \mathrm{~mm}$

Neutral axis Depth

$17.50 \mathrm{~mm}(\mathrm{~d} / 2)$

(Assumed)

Aluminium purlin moment of inertia (From AutoCAD)

$45241.96 \mathrm{~mm}^{4}$

Maximum moment capacity of aluminium purlin

$$
\boldsymbol{M}=\frac{\boldsymbol{f}}{\boldsymbol{I}} * \boldsymbol{y}
$$

$\boldsymbol{f}=$ Tensile strength of Aluminium purlin

$\boldsymbol{I}=$ Moment of inertia of Aluminium purlin

$\boldsymbol{y}=$ Centroid of Aluminium purlin

$$
M=\frac{195}{17.5} * 45241.96
$$

\section{$0.50 \mathrm{kN}-\mathrm{m}$ \\ (Not Safe as \\ $0.5 \mathrm{kNm}<0.68 \mathrm{kNm})$}

Moment due to Load on purlin

\section{$0.68 \mathrm{kN}-\mathrm{m}$}

For the structure to be safe the moment due to wind load on purlin should be less than the moment capacity of aluminium purlin. In this case it is not so, therefore section has to be revised by increasing the width of Star purlin to $45 \mathrm{~mm}$.

Tensile strength

195.00MPa

Width of purlin

$45.00 \mathrm{~mm}$

Height of purlin

$35.00 \mathrm{~mm}$

Thickness

$2.40 \mathrm{~mm}$

Neutral axis Depth

$17.50 \mathrm{~mm}(\mathrm{~d} / 2)$

(Assumed)

Aluminium purlin moment of $66454.9 \mathrm{~mm}^{4}$ inertia (From AutoCAD)

Maximum moment capacity of aluminium purlin

$$
M=\frac{195}{17.5} * 66454.9
$$

$0.74 \mathrm{kN}-\mathrm{m}$

Moment due to Load on purlin
The maximum moment carrying capacity of aluminium purlin is greater than moment due to wind load, which indicates that revised Star section is Safe.

\section{Bolt capacity}

Shear, Bearing and Tension Capacity of the Bolt

\section{Design Parameters}

Diameter of the bolt

Nominal diameter of bolt

Thickness of plate

Minimum Pitch distance

Minimum Edge distance

Maximum Pitch distance

Maximum Edge distance

Ultimate tensile strength of a bolt

Yield stress of the bolt

Ultimate tensile strength of a plate

Number of shear planes with threads intercepting the shear plane

Number of shear planes without threads intercepting the shear plane

Number of bolts provided

Partial safety factor for bolted

connection with bearing

type bolts

Partial safety factor against

yield

stress and buckling

Nominal plain shank area of the bolt

\begin{tabular}{|c|c|}
\hline$d$ & $8 \mathrm{~mm}$ \\
\hline$d_{o}$ & $10 \mathrm{~mm}$ \\
\hline$t$ & $2.40 \mathrm{~mm}$ \\
\hline $\boldsymbol{P}_{\min }$ & $\begin{array}{l}20 \mathrm{~mm} \\
\mathrm{Cl10.2.2})\end{array}$ \\
\hline $\boldsymbol{e}_{\min }$ & $\begin{array}{l}\text { 15mm(IS800, } \\
\text { Cl10.2.4.2) }\end{array}$ \\
\hline $\boldsymbol{P}_{\max }$ & $\begin{array}{l}77 \mathrm{~mm}(\mathrm{IS} \\
800, \mathrm{Cl} 10.2 .3 .1)\end{array}$ \\
\hline$e_{\max }$ & $\begin{array}{l}47 \mathrm{~mm} \quad \text { (IS } 800 \\
\text { Cl10.2.4.3) }\end{array}$ \\
\hline$f_{u b}$ & $195 \mathrm{~N} / \mathrm{mm}^{2}$ \\
\hline$f_{y b}$ & $156 \mathrm{~N} / \mathrm{mm}^{2}\left(0.8 \mathrm{f}_{\mathrm{ub}}\right)$ \\
\hline$f_{u}$ & $195 \mathrm{~N} / \mathrm{mm}^{2}$ \\
\hline$n_{n}$ & 1.00 \\
\hline$n_{s}$ & 0.00 \\
\hline$n_{b}$ & 1.00 \\
\hline${ }^{\gamma}{ }_{m b}$ & 1.25 \\
\hline$\gamma_{m 0}$ & 1.10 \\
\hline$A_{s b}$ & $50.26 \mathrm{~mm}^{2}$ \\
\hline$A_{n b}$ & $40.20 \mathrm{~mm}^{2}$ \\
\hline
\end{tabular}

Net shear area of the bolt at threads

\section{Shear Capacity of Bolt}

Nominal shear capacity of the bolt

$V_{n s b} \quad 4.53 \mathrm{kN}$

Design strength of the bolt

$V_{d s b}$

$3.62 \mathrm{kN}$

\section{Bearing Capacity of Bolt}

$\begin{array}{lll}\text { Reduction factor } & \boldsymbol{K}_{\boldsymbol{b}} & 0.417 \\ \begin{array}{l}\text { Nominal bearing capacity } \\ \text { of a bolt }\end{array} & \boldsymbol{V}_{\boldsymbol{n} \boldsymbol{p} \boldsymbol{b}} & 3.90 \mathrm{kN} \\ \begin{array}{l}\text { Design bearing capacity of } \\ \text { a bolt }\end{array} & \boldsymbol{V}_{\boldsymbol{d} \boldsymbol{p} \boldsymbol{b}} & 3.12 \mathrm{kN} \\ & & \end{array}$


NOTE: The design strength of the bolt shall be taken as the smaller of the value as governed by shear $\left(\mathrm{V}_{\mathrm{dsb}}\right)$ and bearing $\left(\mathrm{V}_{\mathrm{dpb}}\right)$.
Bolt capacity
$V_{d b}$
$3.12 \mathrm{kN}$

\section{Tension Capacity}

Design tension capacity of $\boldsymbol{T}_{\boldsymbol{d} b} \quad 7.06 \mathrm{kN}$ bolt

Total tensile force in the $\boldsymbol{T}_{\boldsymbol{b}} \quad 4.45 \mathrm{kN}$

bolt

Reaction at Purlins where bolt

connects

$1.21 \mathrm{kN}$

\section{Bolt Capacity}

Shear, Bearing and Tension Capacity of the Bolt

\section{Design Parameters}

\begin{tabular}{|c|c|c|}
\hline Diameter of the bolt & $d$ & $6 \mathrm{~mm}$ \\
\hline Nominal diameter of bolt & $d_{o}$ & $8 \mathrm{~mm}$ \\
\hline Thickness of plate & $t$ & $2.40 \mathrm{~mm}$ \\
\hline Minimum Pitch distance & $\boldsymbol{P}_{\min }$ & $\begin{array}{l}15 \mathrm{~mm} \\
\mathrm{Cl} 10.2 .2)\end{array}$ \\
\hline Minimum Edge distance & $e_{\min }$ & $\begin{array}{l}12 \mathrm{~mm}(\mathrm{IS} 800 \\
\mathrm{Cl10.2.4.2)}\end{array}$ \\
\hline Maximum Pitch distance & $\boldsymbol{P}_{\max }$ & $\begin{array}{l}77 \mathrm{~mm}(\mathrm{IS} \\
800, \mathrm{Cl} 10.2 .3 .1)\end{array}$ \\
\hline Maximum Edge distance & $e_{\max }$ & $\begin{array}{l}47 \mathrm{~mm} \quad \text { (IS } 800 \\
\text { Cl10.2.4.3) }\end{array}$ \\
\hline $\begin{array}{l}\text { Ultimate tensile strength of } \\
\text { a bolt }\end{array}$ & $f_{u b}$ & $195 \mathrm{~N} / \mathrm{mm}^{2}$ \\
\hline Yield stress of the bolt & $f_{y b}$ & $156 \mathrm{~N} / \mathrm{mm}^{2}\left(0.8 \mathrm{f}_{\mathrm{ub}}\right)$ \\
\hline $\begin{array}{l}\text { Ultimate tensile strength of } \\
\text { a plate }\end{array}$ & $f_{u}$ & $195 \mathrm{~N} / \mathrm{mm}^{2}$ \\
\hline $\begin{array}{l}\text { Number of shear planes } \\
\text { with threads intercepting the } \\
\text { shear plane }\end{array}$ & $n_{n}$ & 1.00 \\
\hline $\begin{array}{l}\text { Number of shear planes } \\
\text { without threads intercepting } \\
\text { the shear plane }\end{array}$ & $\boldsymbol{n}_{\mathrm{s}}$ & 0.00 \\
\hline Number of bolts provided & $n_{b}$ & 1.00 \\
\hline $\begin{array}{l}\text { Partial safety factor for } \\
\text { bolted } \\
\text { connection with bearing } \\
\text { type bolts }\end{array}$ & $\gamma_{m b}$ & 1.25 \\
\hline $\begin{array}{l}\text { Partial safety factor against } \\
\text { yield } \\
\text { stress and buckling }\end{array}$ & $\gamma_{m o}$ & 1.10 \\
\hline $\begin{array}{l}\text { Nominal plain shank area of } \\
\text { the bolt }\end{array}$ & $A_{s b}$ & $28.27 \mathrm{~mm}^{2}$ \\
\hline $\begin{array}{l}\text { Net shear area of the bolt at } \\
\text { threads }\end{array}$ & $A_{n b}$ & $22.62 \mathrm{~mm}^{2}$ \\
\hline
\end{tabular}

\section{Shear Capacity of Bolt}

Nominal shear capacity of the bolt

Design strength of the bolt

\section{Bearing Capacity of Bolt}

$\begin{array}{lll}\text { Reduction factor } & \boldsymbol{K}_{\boldsymbol{b}} & 0.375 \\ \begin{array}{l}\text { Nominal bearing capacity } \\ \text { of a bolt }\end{array} & \boldsymbol{V}_{\boldsymbol{n} \boldsymbol{p} \boldsymbol{b}} & 2.63 \mathrm{kN} \\ \begin{array}{l}\text { Design bearing capacity of } \\ \text { a bolt }\end{array} & \boldsymbol{V}_{\boldsymbol{d} \boldsymbol{p} \boldsymbol{b}} & 2.10 \mathrm{kN} \\ & \end{array}$

NOTE: The design strength of the bolt shall be taken as the smaller of the value as governed by shear $\left(\mathrm{V}_{\mathrm{dsb}}\right)$ and bearing $\left(\mathrm{V}_{\mathrm{dpb}}\right)$.

$\begin{array}{lll}\text { Bolt capacity } \quad V_{d b} & 2.04 \mathrm{kN}\end{array}$

\section{Tension Capacity}

Design tension capacity of $\boldsymbol{T}_{\boldsymbol{d} b} \quad 3.97 \mathrm{kN}$ bolt

Total tensile force in the $\boldsymbol{T}_{\boldsymbol{b}} \quad 4.45 \mathrm{kN}$ bolt

Reaction at Purlins where bolt connects

\section{Pull-out Force Calculation}

\begin{tabular}{|c|c|c|}
\hline Shear stress $=\frac{\sigma_{t}}{\sqrt{3}}$ & $\tau$ & $112.50 \mathrm{~N} / \mathrm{mm}^{2}$ \\
\hline $\begin{array}{l}\text { Tensile yield stress or } \\
\text { design stress }\end{array}$ & $\sigma_{t}$ & $195 \mathrm{~N} / \mathrm{mm}^{2}$ \\
\hline Pitch diameter & $\mathbf{D}_{\mathbf{p}}$ & \\
\hline $\begin{array}{l}\text { Axial length of full thread } \\
\text { engagement }\end{array}$ & $\mathbf{L}$ & $0.00159 \mathrm{~mm}$ \\
\hline Safety factor & $\mathbf{S}$ & 1.8 \\
\hline Pull-out Force & $\mathbf{F}$ & $2.50 \mathrm{kN}$ \\
\hline
\end{tabular}

Pull out force of bolt should always be greater than reaction at purlin where bolt connects. Hence safe.

\section{CONCLUSION}

The study provides the importance of Analysis with respect to selection of purlins in accordance with their stability and durability against the Forces acting due to self-weight and wind forces .The following conclusions are derived from the study performed.

- The length, width and thickness of the section are main key factor for influencing in increasing/decreasing in moment of inertia of the section. The moment of inertia of the section is the resulting parameter which decides the stability of the type and profile of the purlin section.The study indicates that purlin with higher moment of inertia has better moment carrying capacity. The U-Purlin offers better moment carrying capacity compared to higher star section.

- The capacity of bolt is governed by various parameters like tensile strength, diameter of bolt/screw, length etc. the results from our study specifies that the stability of panel is directly dependent on number of bolts provided around the panel.

- The resulting reaction forces at the connections of solar panel to the supporting purlin is the limiting factor for 
pull-out force of screws. The result from the study specifies that bolts with better shear capacity and axial length of the full thread engagement of screws offer better resistance against pull-out forces over the solar panel.

- Post installation studies indicate that the pitched roofs offer better energy output from P.V panels.

- The reactions forces calculated in accordance with IS 875 for wind loads are fairly accurate to that of the values obtained using professional structural analysis package like Stadd-pro.

\section{REFERENCES}

[1] Stephen Dwyer, Alan Harper, William Lindau, Tom Bosiljevac, Kay Schindel and Elizabeth Richards: "Structural Considerations for Solar Installers", Dec 2011.

[2] EleniXypnitou, "Wind Load on Solar Panel Systems Attached to Building Roof", Aug 2012.

[3] A. Mihailidis, K. Panagiotidis and K. Agouridas , "Analysis of Solar Panel Support Structures", Sept 2009.

[4] IS: 875 (Part I) -1987, Code of Practice for Design Loads (Other than Earthquake) for Buildings and Structures. Part I dead loads - unit weights of building materials and stored materials

[5] IS: 875 (Part II) -1987, Code of Practice for Design Loads (Other than Earthquake) for Buildings and Structures.Part II imposed loads.

[6] IS: 875 (Part III) -1987, Code of Practice for Design Loads (Other than Earthquake) for Buildings and Structures.Part III wind Loads

[7] IS 800:2007, General Constructions in Steel-Code of Practice. 